Management and Economics Journal

E-ISSN : 2598-9537 P-ISSN : 2599-3402

Journal Home Page: http://ejournal.uin-malang.ac.id/index.php/mec

Volume 4 Number 3, December 2020

\title{
The Impact of Understanding Economic Literacy and Lifestyle on Entrepreneurial Intention of Students in Higher Education
}

\begin{abstract}
Ananda Setiawan*
Lambung Mangkurat University, Banjarmasin, Indonesia ananda.setiawan@ulm.ac.id
\end{abstract}

\section{Budi Eko Soetjipto}

Malang State University,

Malang, Indonesia

budi.eko.fe@um.ac.id

Ery Tri Djatmika Rudijanto

Malang State University,

Malang, Indonesia

ery.try.fe@um.ac.id

\begin{abstract}
The importance of understanding economic literacy, controlling lifestyle, and enhancing student entrepreneurial intentions should not be overlooked. This study aimed to determine the impact of understanding economic literacy and lifestyle on student entrepreneurial intentions. This research is included in a quantitative descriptive study using multiple regression analysis techniques. This study's population were all students of economic education at Lambung Mangkurat University, as many as 267 students. The sample size taken was 157 people by random sampling. The data collection technique used a questionnaire. This study's results indicate that students' economic literacy has a positive and significant impact on entrepreneurial intentions, lifestyle has a positive and significant impact on students' entrepreneurial intentions, and simultaneously economic literacy and lifestyle have a positive and significant impact on entrepreneurial intentions. The coefficient of determination of economic literacy and lifestyle on entrepreneurial intentions is $38 \%$. From these results, it can be concluded that economic literacy and lifestyle positively and positively impact entrepreneurial intentions.
\end{abstract}

Keywords: Economics Literacy, Lifestyle, Entrepreneurial Intention

Received June 2020 | Accepted November 2020 | Available online December 2020

| DOI: http://dx.doi.org 10.18860/mec-j.v4i3.9565

\section{INTRODUCTION}

Humans have needs to be fulfilled. The increase in human life necessities is triggered because of the advancement of science and technology that has found transition and changing times. Capitalism always urges people to consume more and more. Residents buy goods that no longer need to grant ambitions to consume beyond this limit, resulting in consumer behavior patterns. At the initial observation, it was found that the consumptive behavior of students was very high. Then, the reason for consuming is because the goods are needs and follow the lifestyle.

Economic literacy has a very close relationship with the knowledge of economic behavior. Economics is studying human endeavors to fulfill life necessities and study events to achieve prosperity (Hadi, 2013). Then, Sina (2012) argues that economic literacy 
is one of the tools that benefit from changing a person's behavior from being unintelligent to being intelligent. As well as meeting the needs of life, the crew uses the income to save and invest. With the existence of economic literacy, it is said to minimize consumption behavior in consumption activities. Similarly, what was revealed by Budiwati (2014) low economic literacy will lead to a consumerist attitude. This knowledge links to economic problems and has a good understanding of business money and economic problems (Pandey \& Bhattacharya, 2012; Kotte and Witt, 1995).

According to Salemi (2005), economic literacy is also defined as understanding and applying basic economic concepts. So, it can be concluded that, in general, economic literacy is knowledge, understanding of concepts, basic principles of economics, and practical aspects of knowledge governing economics obtained while in the classroom.

Lifestyle is a picture of a person's lifestyle applied in his activities, interests, and opinions (Astuti, 2016). Setiadi (2015) state that lifestyle, in general, is described as a way of life that is expressed by how a person fills all the time they have, what feels critical in their environment and how they think about themselves and the surrounding environment.

Lifestyle can be said as a pattern of action that will become the boundary between one person and another person. We can find a person's lifestyle ideas without first clarifying what we mean by interacting in daily life. Therefore, lifestyle will make someone understand what they will do, why they do it, and whether they benefit. However, this notion of lifestyle is not always seen in differences in consumption patterns, but the same thing will also happen when viewed from the behavior patterns of individuals who have choices, even with the same resources.

Entrepreneurial intention is understood as prospective entrepreneurs' personal commitment to start a new business, which then becomes a bridge between attitudes, subjective norms, and behavioral control over actual behavior (Tung, 2011). The intention is to represent actions planned to carry out entrepreneurial behavior because before starting a business, a strong commitment is needed to initiate it (Tubbs and Ekeberg, 1991). Entrepreneurial intention becomes a tendency for individuals to take entrepreneurial actions by creating new products through business opportunities and risk-taking (Ramayah and Harun, 2005). Furthermore, Rasli et al. (2013) define entrepreneurial intentions as thoughts that encourage individuals to create businesses, so that intentions are needed as a first step in establishing a generally long-term business (Lee and Wong, 2004).

Wirawan \& Puspitaningsih (2019); Sahroh (2018) explains a positive relationship between economic literacy and entrepreneurial intentions. So, it is necessary to confirm the findings at Lambung Mangkurat University to find out whether there is a positive relationship between economic literacy and entrepreneurial intentions. Based on previous research, the research hypotheses are to find out:

H1: economic literacy has a positive and significant impact on entrepreneurial intentions

H2: lifestyle has a positive and significant impact on entrepreneurial intentions 
H3: economic literacy and lifestyle have a positive and significant impact on entrepreneurial intentions.

This study's research objective was to determine the impact of economic literacy on entrepreneurial intentions, the impact of lifestyle on entrepreneurial intentions, and the impact of economic literacy and lifestyle on entrepreneurial intentions.

\section{METHODOLOGY}

This type of research is quantitative research. The research subjects were students at the Department of Economic Education of Lambung Mangkurat University, with a sample of 157 students reached through a sampling technique that is incidental random sampling.

Data collection techniques used by using a questionnaire or questionnaire. The questionnaire measurement scale uses a Likert scale. The instrument test in this study was conducted on respondents as an initial sample of 30 students. The prerequisite test analysis in this study uses (1) normality test, (2) linearity test (3) multicollinearity test. (4) heteroscedasticity test (5) autocorrelation test. Data analysis techniques using quantitative approaches, descriptive analysis techniques, hypothesis testing, and multiple linear regressions.

\section{DISCUSSION}

\section{Description of Research Variables}

Table 1. Results of descriptive analysis of economic literacy

\begin{tabular}{cllc}
\hline Variable & Indicators & $\%$ & Criteria \\
\hline economic & Microeconomics: & & \\
literacy & Main Economic Issues & & \\
& Market and Prices & & \\
& Supply and Demand & $54,35 \%$ & \\
& Macroeconomics: & & \\
& The role of the government & & \\
& Fiscal and Monetary Policy & & \\
\hline
\end{tabular}

Based on the study results, note that table 1 shows that the economic literacy variable is $54.35 \%$, which means that it is included in the high category criteria. Five indicators serve as benchmarks for economic literacy, such as the description of the table above. Indicators of market material and prices are higher than other indicators, and indicators of the subject matter of economic problems are the smallest percentage of material than other indicators. Based on this, it can be concluded that the highest percentage of economic literacy knowledge is about the market and prices. 
The Impact of Understanding Economic Literacy and Lifestyle .....

Table 2. Lifestyle Descriptive Analysis Results

\begin{tabular}{clcc}
\hline Variable & Indicators & $\%$ & Criteria \\
\hline Lifestyle & Activity & & \\
& $\begin{array}{l}\text { Interest } \\
\text { Opinion }\end{array}$ & $46,32 \%$ & medium \\
\hline
\end{tabular}

Based on the study results, note that the lifestyle variable is $46,32 \%$, which means it is included in the medium criteria category. Three indicators measure lifestyle, as described in the table above. The opinion indicator has the highest percentage among other indicators, and the smallest is the activity indicator. Based on this, it can be concluded that students of economic education study programs possess a moderate category lifestyle.

Table 3. Results of descriptive analysis of entrepreneurial intentions

\begin{tabular}{llll}
\hline \multicolumn{1}{c}{ Variable } & Indicators & $\%$ & criteria \\
\cline { 2 - 3 } $\begin{array}{l}\text { Entrepreneurial } \\
\text { Intention. }\end{array}$ & $\begin{array}{l}\text { develop themselves in creating } \\
\text { businesses } \\
\text { choose a career as an } \\
\text { entrepreneur } \\
\text { work together to get started } \\
\text { looking for opportunities }\end{array}$ & $33,21 \%$ & medium \\
& & & \\
\hline
\end{tabular}

Based on the study results, note that the intention of entrepreneurship is $33,21 \%$, which means it is included in the medium criteria category. Four indicators serve as benchmarks in entrepreneurship intentions, as noted in the table above. The indicator for pleasure has the highest percentage among other indicators, and the smallest is the indicator of satisfaction. Based on this, it can be concluded that students conduct consumptive behavior aimed at seeking pleasure.

Table 4. Multicollinearity Test

\begin{tabular}{cccc}
\hline Variable & Tolerance & VIF & Explanation \\
\hline $\begin{array}{c}\text { economic } \\
\text { literacy }\end{array}$ & 0,999 & 1,001 & there is no \\
Lifestyle & 0,999 & 1,001 & multicollinearity \\
\hline
\end{tabular}

VIF value $<10=1,001<10$ and tolerance value 0,10. Therefore 0,999 $>0,10$, which means there is no multicolliniarity.

Table 5. Autocorrelation Test

\begin{tabular}{c}
\hline Durbin-Watson \\
\hline 1,976
\end{tabular}

In Table 5 DW the significance level of $5 \% \mathrm{dl}=1,711$ and $\mathrm{du}=1,7649$ autocorrelation test results show the value of DW $=1,976$ and $\mathrm{du}<\mathrm{d}<4$-du or $1,7649<1,976<4-1,7649$, then the conclusion does not occur autocorrelation. 


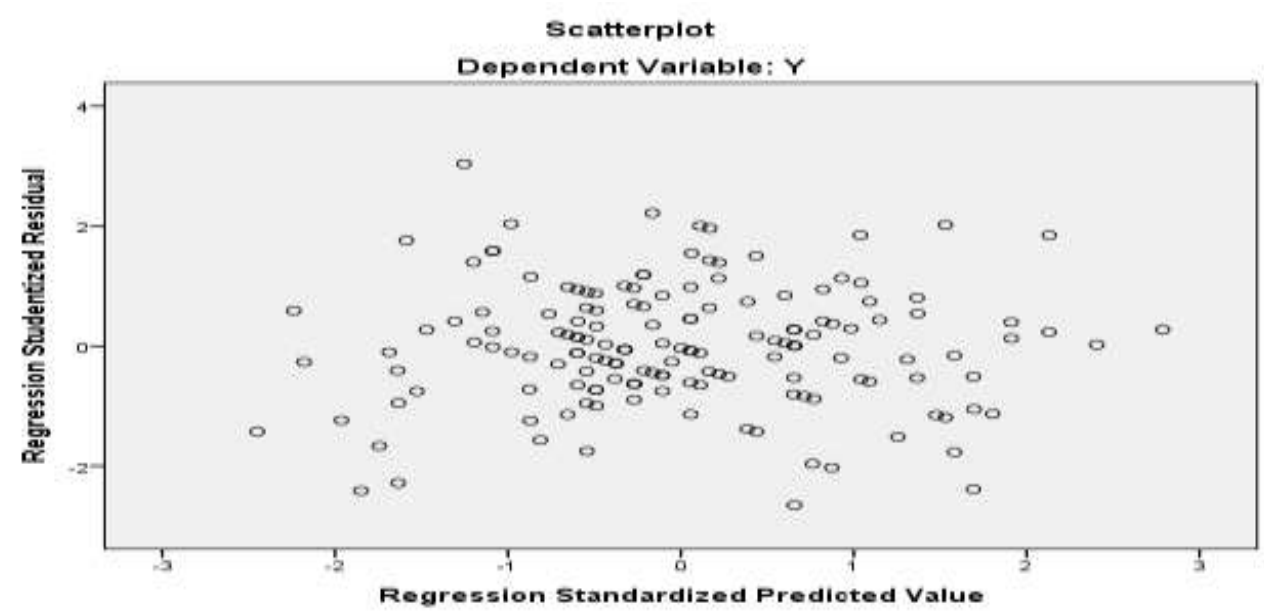

Figure 1. Heteroscedasticity Test Results

The point spreads above \& below the number 0 on the $\mathrm{Y}$-axis, so there is no heteroscedasticity.

\section{Hypothesis test}

Table 6. Results of Multiple Linear Regression Tests

\begin{tabular}{|c|c|c|c|c|c|}
\hline \multirow[t]{2}{*}{ Model } & \multicolumn{2}{|c|}{ Unstandardized coefficients } & \multirow{2}{*}{$\begin{array}{r}\begin{array}{l}\text { Standardized } \\
\text { coefficients }\end{array} \\
\text { Beta }\end{array}$} & \multirow[t]{2}{*}{$T$} & \multirow[t]{2}{*}{ Sig } \\
\hline & B & Std. Error & & & \\
\hline (constant) & 38,696 & 4,930 & & 5,643 & 0,000 \\
\hline $\begin{array}{l}\text { economic } \\
\text { literacy }\end{array}$ & ,409 & ,086 & ,256 & 4,453 & 0,001 \\
\hline Lifestyle &, 561 & ,064 &, 550 & 7,453 & 0,000 \\
\hline
\end{tabular}

Based on Table 6 calculations, it was obtained that the economic literacy variable t count $=4,453$, the score obtained as significant as 0,001 with sig $<0,05$ means that significant or there is a positive effect of economic literacy on student entrepreneurial intentions. This means that with every increase of one economic literacy variable, it will increase the student's spiritual intention.

Based on calculations from Table 6 , the $t$-count for lifestyle variables is $t$ count $=7,453$, while a significance value of $0,000<0,05$ is obtained, meaning that there is a significant or positive effect between lifestyle and entrepreneurial intention of students. If the lifestyle variable has an increase in the meaning of student entrepreneurial intention increases.

Table 7. Multiple Regression Analysis

\begin{tabular}{llccccc}
\hline Model & & Sum of Squares & Df & Mean Square & $F$ & Sig. \\
\hline \multirow{2}{*}{1} & Regression & 1239,989 & 2 & 619,994 & 33,281 & $0,000^{\mathrm{b}}$ \\
\cline { 2 - 7 } & Residual & 2200,929 & 154 & 24,292 & & \\
\cline { 2 - 7 } & Total & 3440,917 & 156 & & & \\
\hline
\end{tabular}


In Table 7, it is known that by using a sig level of 0,05, the value of F-count is 33,281 and the value of sig $0,000<0,05$, it can be concluded that economic literacy and lifestyle influence simultaneously on student entrepreneurial intentions.

Table 8. Determinant coefficient

\begin{tabular}{ccccc}
\hline Model & $\mathrm{R}$ & $\mathrm{R}$ Square & Adjusted R Square & Std. Error of the Estimate \\
\hline 1 & $0,530^{\mathrm{a}}$ & 0,380 & 0,352 & 3,780 \\
\hline
\end{tabular}

Based on Table 8 , obtained R-Square of 0,380 or $38 \%$. This illustrates the effect of economic literacy and lifestyle on entrepreneurial intentions by $38 \%$, while $62 \%$ influences other factors outside the model. In Table 8 , it is explained that at a significance level of 0.05 and degrees of freedom df ( $(n-2)$ or $157-2=150, r$ count $=0,530$ is obtained, while $r$ table $=0,153$. Thus $r$ count $>r$ table $(0,530>0,153)$. R-value of 0,530 indicates the coefficient of $\mathrm{R}$. The results of the study variables are included in the strong category. Then, it can be concluded that there is a significant influence between economic literacy and lifestyle on student entrepreneurial intentions.

\section{DISCUSSION}

Economic literacy has a positive and significant effect on the entrepreneurial intentions of economic education students. Suppose seen from the results of $t$-test calculations that show economic literacy effects on entrepreneurial intentions by 0,409 . These results illustrate that the higher the level of literacy possessed by students, the students' consumptive behavior becomes rational and vice versa. To prevent consumptive behavior, it can be anticipated by having excellent and adequate economic literacy. This is in line with research Solihat \& Arnasik (2018); Sahroh (2018) found that economic literacy positively and significantly impacts entrepreneurial intentions. Having high economic literacy since studying in education is expected to be an excellent first step in determining entrepreneurial interest in the future, explained by Japelli (2010), who emphasizes that economic literacy is critical in determining student economic behavior.

Lifestyle has a positive and significant effect on entrepreneurial intention students. If seen from the t-test calculation results proves that lifestyle influences students' entrepreneurial intentions by 0,561 . These results illustrate that the higher the lifestyle, the more entrepreneurial intentions students have. Lifestyle is an individual authority. This is in line with the opinion (Lieli \& Sirine, 2011). There is a need for control from the family to control the lifestyle because the family influences entrepreneurial interest (Walipah \& Naim, 2016). Then, economic literacy and lifestyle have a positive influence on entrepreneurial intentions. This simultaneous influence shows that students must be able to improve economic literacy and lifestyle together to increase entrepreneurial intentions. Students who have entrepreneurial intentions are expected to be able to have a business independently. Economic literacy and lifestyle can increase student entrepreneurial intentions so that efforts are needed to improve economic literacy and lifestyle. 


\section{CONCLUSION}

Economic literacy is $65,45 \%$, which is included in the high category. The percentage for lifestyle is $59,79 \%$, including the medium category. The R-square research explains that the impact of economic literacy and lifestyle on entrepreneurial intentions is 0,380 (38\%). So, students need to increase economic literacy and a rational lifestyle in order to increase entrepreneurial intentions.

\section{REFERENCES}

Astuti, R. P. F. (2016). Pengaruh Status Sosial Ekonomi Orang Tua, Literasi Ekonomi Dan Life Style Terhadap perilaku Konsumsi mahasiswa Jurusan Pendidikan Ekonomi IKIP PGRI Bojonegoro. Jurnal Pendidikan Edutama, 3(2), 46-58. DOI: 10.30734/jpe.v3i2.36.

Budiwati, N. (2014) . Analisis Literasi Ekonomi dan Perilaku Konsumen (Survey pada Guru SMA di Kota Bandung). (Disertasi). Bandung : Universitas Pendidikan Indonesia.

Hadi, R. (2013). Pengantar Ilmu Ekonomi. Banjarmasin: P3Al Universitas Lambung Mangkurat Banjarmasin

Japelli, T. (2010). Economic Literacy Economic Literacy: An International Comparison.

Jenkins, M. \& Johnson, G. (1997). Entrepreneurial Intentions and Outcomes: A Comparative Causal Mapping Study. Journal Management Studies, 34 (6), 895-920. DOI: $10.1111 / 1467-6486.00077$.

Kotte \& Witt. (2005). Chance and challenge: Assessing Economic Literacy. Technical University Dreden School of Economics. 159-168. Received from https://www.waxmann.com/fileadmin/media/zusatztexte/postlethwaite/kotte.pdf.

Lee, S.H. \& Wong, P.K. (2004). An Exploratory Study Of Technopreneurial Intentions: A Career Anchor Perspective. Journal Of Business Venturing, 19(1): 7-28.

Lieli, S. \& Sirine, H. (2011). Faktor-Faktor yang Berpengaruh Terhadap Niat Kewirausahaan (Entrepreneurial Intention). Jurnal Manajemen dan Kewirausahaan, 13(2), 124-134. DOI: 10.9744/jmk.13.2.124-134.

Pendey. C \& Bhattacharya. (2012). Economic Literacy of Senior Secondary School Teachers: A Field Study. Journal of all India Association for educational research. 24(1) 1-16. Received from https://silo.tips/download/economic-literacy-of-seniorsecondary-school-teachers-a-field-study\#.

Ramayah, T \& Harun. (2005). Entrepreneurial Intention Among The Studen Of University Sains Malaysia (USM). International Journal Of Management And Entrepreneurship, 1: 8-20

Rasli, A., Khan, S.U.R., Malekifar, S \& Jabeen, S. (2013). Factors Affecting Entrepreneurial Intention Among Graduate Students of Universiti Teknologi Malaysia. International Journal of Business and Social Science, 4(2): 182-188.

Sahroh, A. F. (2018). Pengaruh Literasi Ekonomi Dan Tingkat Penggunaan Media Sosial Terhadap Minat Berwirausaha Mahasiswa Fakultas Ekonomi Di Universitas Negeri Surabaya. Jurnal Pendidikan Ekonomi (JUPE), 6(3). DOI: 10.26740/jupe.v6n3.p\%p 
Salemi, M. K. (2005). Teaching Economic Literacy: Why, What, and How. International Review of Economics Education, 4(2), 46-57. DOI: 10.1016/S1477-3880(15)30132-8.

Setiadi, N. (2015). Perilaku Konsumen. Jakarta: Prenamedia Group

Sina, P. G. (2012). Analisis Literasi Ekonomi. Jurnal Economia Universitas Negeri Yogyakarta, 8(2), 135-143. DOI: 10.21831/economia.v8i2.1223.

Solihat, A. N \& Arnasik. S. (2018). Pengaruh Literasi Ekonomi Terhadap Perilaku Konsumtif Mahasiswa Jurusan Pendidikan Ekonomi Universitas Siliwangi. Oikos: Jurnal Kajian Pendidikan Ekonomi dan Ilmu Ekonomi, 2(1), 1-12. DOI: 10.23969/oikos.v2i1.915

Sugiyono. (2018). Metode penelitian Pendidikan Kuantitatif. Bandung: PT. Alfabeta

Tubbs, M. E., \& Ekeberg, S. E. (1991). The role of intentions in work motivation: Implications for goal-setting theory and research. The Academy of Management Review, 16(1), 180-199. DOI 10.2307/258611.

Tung, L. C. (2011). The impact of entrepreneurship education on entrepreneurial intention of engineering students., Ph.D. Thesis, City University of Hong Kong, 36.

Wahyudi. (2013). Tinjauan tentang Perilaku Konsumtif Remaja Pengunjung Mall Samarinda Central Plaza. eJournal sosiologi, 1(4), 26-36. Received from http://ejournal.sos.fisip-unmul.ac.id/site/?p=613.

Walipah, W., \& Naim, N. (2016). Faktor - Faktor Yang Mempengaruhi Niat Berwirausaha Mahasiswa. Jurnal Ekonomi Modernisasi, 12(3), 138-144. DOI: 10.21067/jem.v12i3.1461

Wirawan, Y. R \& Puspitaningsih, F. (2019). Pengaruh Literasi Ekonomi dan Pengalaman Prakerin terhadap Minat Berwirausaha Peserta Didik Kelas XI Kompetensi Keahlian Administrasi Perkantoran (APK) SMK Negeri 1 Pogalan Tahun Pelajaran 2017/2018. Equilibrium, 7(2), 106-115. DOI:10.25273/equilibrium.v7i2.4787 